\title{
The Development of Multimedia-Based Digital Simulation E-Book For Vocational Schools
}

\author{
Nurhikmah $\mathbf{H}^{\mathbf{1}}$, Arnidah $^{\mathbf{2}}$, Haamsar Hasfat ${ }^{3}$ \\ ${ }^{1}$ Educational Technology, Unirvesitas Negeri Makassar, Indonesia \\ Email: nurhikmah.h@unm.ac.id \\ ${ }^{2}$ Educational Technology, Unirvesitas Negeri Makassar, Indonesia \\ Email: arnidah@unm.ac.id \\ ${ }^{3}$ Educational Technology, Unirvesitas Negeri Makassar, Indonesia \\ Email: id.hamsar@gmail.com
}

(Received: 07-01-2021; Reviewed: 08-02-2021; Accepted: 20-04-2021; Available online: 21-04-2021; Published: 25-04-2021)

\begin{abstract}
This research is development research aimed to develop a learning product in the form of a Multimedia-based E-book on Digital Simulation Subjects which are feasible or valid and easy to use or practical. The test subjects in this research and development consisted of content experts, media experts and subject teachers of digital simulation and grade 10th students of SMK Negeri 4 Gowa. The ADDIE development model used in this study consisted of five stages, namely: (1) analysis stage, (2) design stage, (3) development stage, (4) implementation stage (5) evaluation stage. The development of multimedia-based digital simulation e-book through the material expert validation stage with the score of 4.73 and media validation 4.60 shows that the material and design or media evaluation in the e-book is feasible or valid. Then, the teacher's response obtained a score of 4.71, the average score of individual student trials was 92.14, and the average score of the student group trial was 90 , which means the e-book is easy to use by teachers and students. there were no students who acquired a low score from the test results after learning using the e-book which means it is effectively used.
\end{abstract}

Keywords: e-book, multimedia, digital simulations

\section{INTRODUCTION}

The theory of learning experiences known as Dale's Cone of Experience put forward by Edgar Dale in cannot describe the level of difficulty of a lesson rather than the abstractness and the number and types of senses used in the process of receiving messages or subject matter. Arsyad explained that this cone is a detailed elaboration of the concept of three levels of experience put forward by Bruner, namely direct experience (enactive), pictorial experience (iconic), and abstract experience (symbolic). First, a person begins to learn through direct experience (concrete), then through artificial objects, to verbal (abstract) images. Direct experience can remain a message and a clearer understanding while getting to the top of the more abstract media to deliver the message because the senses that can be used are limited (Arsyad, 2014).

Learning media is everything that becomes an intermediary in the learning process that is used to convey messages or learning information to stimulate the mind, attention, feelings, and learning skills to encourage the 
occurrence of a good learning process. One type of learning media that can be developed is teaching materials in the form of electronic books (Sanjaya, 2019).

The rapid development of technology has made learning materials and media which is not in printed form or hardcopy but has been transformed into digital form. This is because digital literacy can be done anytime and anywhere, simply by using a smartphone, material in the form of text, images and even videos can be studied at once (Santoso et al., 2018). Miftah (2013) argues that learning media in the form of machines (technology) is seen as a science application that can be in the form of electronic media or other learning machines that occupy a strategic position in facilitating and streamlining learning. The learning reach also becomes wider or distance learning and faster application in learning has a positive contribution to improving the quality of learning. According to Koh \& Herring (2016) Ebooks have various advantages over printed books, including easy access, easy topic search, can be accessed anywhere and anytime, a more attractive appearance, cheaper and practical in storing small files. Meanwhile, Yachina (2016) argued that the distinctive feature of using electronic books compared to printed books is that they provide information not only in the form of text, but also through audio visuals in which it allows students to focus on learning and contribute to better understanding and retention of information.

The learning resource generally used by teachers and students in learning is printed books, this is due to habits that are inherent and carried out continuously (Moller, 2014). Even though with the rapid development of technology, it is time to use e-books in learning to increase the quality of learning with the advantages and benefits obtained by using ebooks.

Electronic Book is commonly referred to as e-book which means electronic books or soft files from printed books. Electronic books contain digital information that can be in the form of text or images (Subiyantoro, 2014). According to Rockinson-Szapkiw (2013), an ebook is a book in digital format (portable) that contains information and a learning database or subject matter to be opened via a computer device. E-books are printed books that have been converted into digital format, through digitalization stages that make them visible on the desktop screen.E-books are designed for readers to be more interactive in digging up information or material, for example through a keyword search tool. The results of Rvachew (2017) study shows that there is a significant difference in student literacy using e-books compared to printed books. This occurs because the ebook can be read via smartphone anytime and anywhere.

The School Electronic Book (BSE) is an example of an e-book used in learning and published by the government as an effort to make it easier for teachers and students to obtain adequate learning resources easily, quickly, and for free. BSE is the conversion of printed books into digital form which is not different in appearance from printed books in general. BSE has the advantage that there is a lot of subject matter, complete with pictures, easily accessible via the internet, legally reproducible, and free. On the other hand, there are shortcomings that BSE has, including static images, no audio, video, and animation media. These deficiencies can lead to boredom and reduce student interest in learning to use these e-books, especially in digital simulation learning in vocational schools, which have more practical learning compared to theory. To overcome this problem, it is necessary to develop a multimedia-based digital simulation e-book for SMK.

Multimedia-based digital simulation ebook for SMK is required as the benefits obtained from learning resources are not only from text but other elements such as videos. Glackin (2014) through the results of his research, the result shows that the use of e-books containing a combination of media elements can have a positive impact on students' learning experiences. Meanwhile, Fojtik (2015) stated that educational institutions must adapt learning methods to technological developments, in this case the use of mobile learning in learning, this causes students to actively use various learning applications or libraries on smartphones to access various learning sources such as e-books.

An e-book which does not only contain pictures but also needs to be added with multimedia is expected to make it easier for students to understand the subject matter. In subjects such as digital simulation required for a multimedia-based e-book in which includes audio, video, and animation.

Materials in Digital Simulation Subjects such as making presentation media, videos and digital books cannot be comprehended by 
students with only text and images, but it is necessary video tutorials which is specifically developed according to the needs and characteristics of students which are bundled in e-books.

\section{METHOD}

This type of research is a research and development used to produce certain products. Research and development according to Putra (2012) is a research method that is deliberate, systematic, aims/directed to seek and find, formulate, improve, develop, produce, test the effectiveness of products, models, methods / strategies /, services, certain procedures that are superior, new, effective, efficient, productive, and meaningful. The goal to be achieved through this research and development is to produce a multimedia-based e-book- that is valid and practical to use.

The test subjects in this research and development consisted of content experts, media experts, and also teachers and students as users of the developed product. The number of trial subjects were one content expert, one media expert, one teacher of digital simulation subject, seven individual trials and sixteen small group trials, and twenty people at the utilization stage. The test subjects were determined by using a purpose sampling technique. Acharya (2013) purpose sampling technique purpose sampling technique is the selection of samples with certain considerations and criteria by research needs but still have limitations and pay attention to data variability.

This research and development are research-oriented to produce or develop a product through a process of validation of feasibility and practicality. Devi (2018) to carry out the development of learning tools requires development models that are in accordance with the education system. A model is a set of sequential procedures for showing a process, such as a needs assessment, media selection, and evaluation. In this case, developers will develop multimedia-based e-book on Digital Simulation Subjects using the ADDIE Model. Januszewski and Molenda (Cahyadi, 2019) suggest that the ADDIE model in designing instructional systems uses a system approach. The essence of the system approach is to divide the learning planning process into steps, organize the steps into logical sequences, then use the output of each step as input in the next step.
This model consists of five phases or stages, namely Analysis, Design, Development, Implementation, and Evaluation. The ADDIE model was chosen because it is a general development model and is appropriate for use in the research and development of learning products (Maribe, 2009).

The procedure for developing a multimedia-based e-book for this Digital Simulation Subject includes five stages, namely: (1) analysis stage, (2) design stage, (3) development stage, (4) implementation stage (5) evaluation. Each stage is carried out continuously to produce learning products that are in accordance with the needs of students. An overview of the multimedia-based e-book development model in Figure 1.

The data analysis technique was carried out qualitatively, compiled from the results of the assessment, input, responses, criticism, and suggestions for improvement through instruments obtained from the assessment of experts, teachers, and students. The results of this data analysis are then used to revise the learning products developed. The multimediabased e-book must be validated before field trials.

The criteria for evaluating expert validation, teacher and student responses use a Likert scale adapted from Anggraini (2014) as in the following table.

Table 1. Instrument Assessment Score Criteria

\begin{tabular}{lc}
\hline Category & The score for each question \\
\hline Very good & 5 \\
Good & 4 \\
Good enough & 3 \\
Not good & 2 \\
Poor & 1 \\
\hline
\end{tabular}

The data obtained from the assessment of expert validation and yield responses of teachers and learners are then processed and analyzed using the following formula.

$\mathrm{P}=\left(\sum \mathrm{X}\right) /\left(\sum \mathrm{X} \_\mathrm{i}\right) \times 100$

Information

P: Percentage

$\sum \mathrm{X}$ : Total assessment score

$\sum X i$ : Highest total score

(Pratama et al., 2019) 
The decision making from the percentage value obtained can be seen through the achievement criteria for the results of media development proposed by Akdon (2013) as in the table 2 .
Table 2. Assessment Percentage Range

\begin{tabular}{ll}
\hline Persentase & Criteria \\
\hline $81 \%-100 \%$ & Very good \\
$61 \%-80 \%$ & Good \\
$41 \%-60 \%$ & Good enough \\
$21 \%-40 \%$ & Not good \\
$\leq 20 \%$ & Poor \\
\hline
\end{tabular}

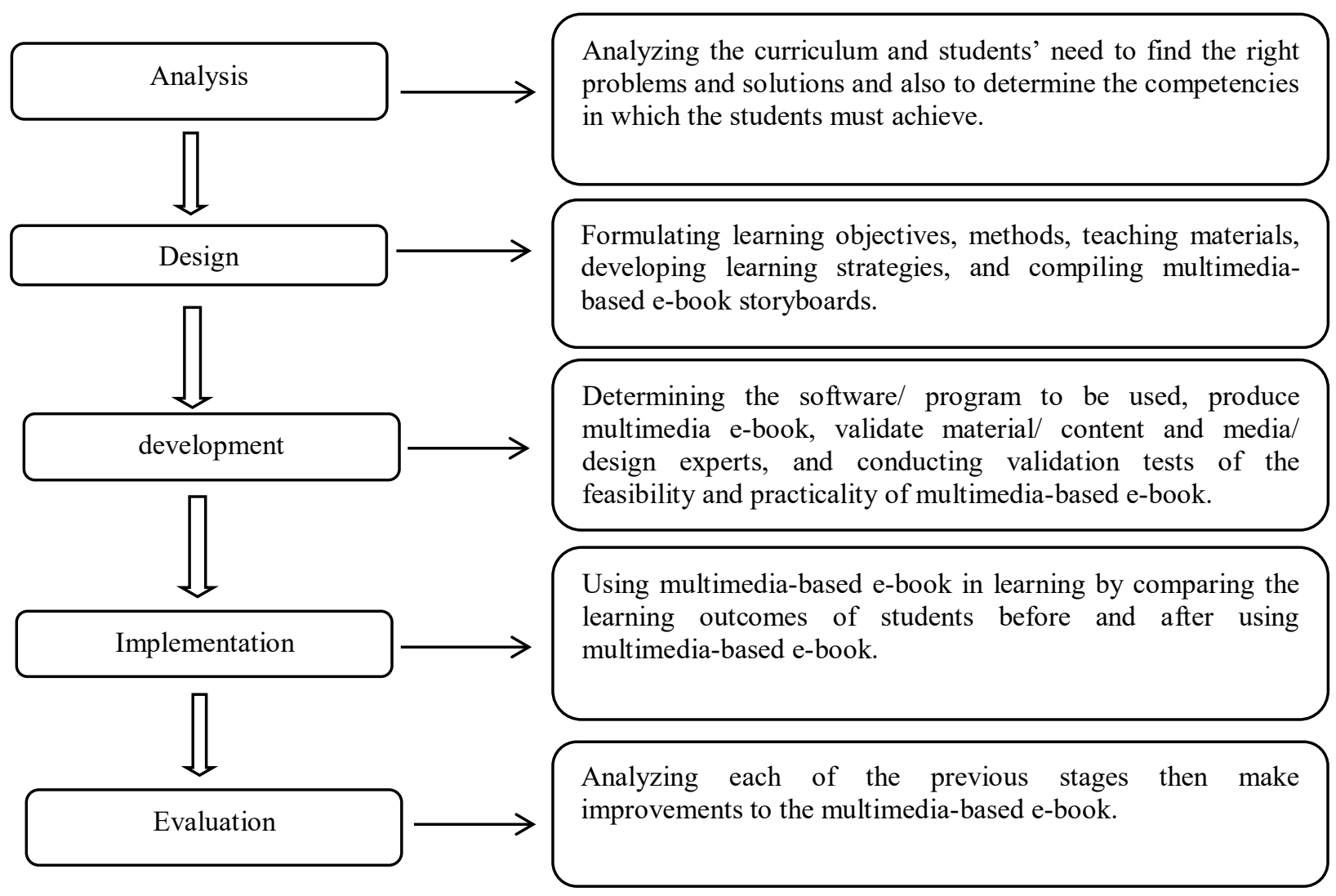

Figure 1. Development Model of Multimedia-Based Digital Simulation e-Book

\section{RESULTS AND DISCUSSION}

\section{Result}

\section{Analysis}

The curriculum analysis was carried out referring to the 2013 curriculum which was updated in 2015 and 2017 which is now referred to as the national curriculum. In conducting curriculum analysis, the developer examines the syllabus and lesson plans used by the teacher in learning. The initial focus of the developer was to see the core competencies and basic competencies that students had to achieve in each subject matter.

Developers examine the syllabus and lesson plans while conducting unstructured interviews with subject teachers and as a result, there were two in the first semester of the subject matter that hones their skills and creativity of learners but has not been able to be implemented properly because of the materials and media used is not appropriate. Teachers find it difficult to design material and media so that they are easily understood by students during learning. 
The teacher has implemented a variety of learning methods in learning, but the digital simulation textbooks used only contain text and pictures, making it difficult for teachers and students to learn. The material in digital simulation subjects requires students to master various programs to solve problems in society that can be solved with technology so that the subject matter combines theory and tutorial using the program, but tutorials in the form of text and images make it difficult for students to know the instructions in the textbook which is still in printed form.

Identify the needs of the students are divided into three aspects: the conditions of the learning process to determine how the condition of the learning process that has been experienced by learners, the material needs to know the subject matter is difficult to be understood by the learner and the needs of learning media to determine the media needed by learners that can increase interest in learning in digital simulation subjects.

The conditions of the Digital Simulation learning process at SMK Negeri 4 Gowa Class $\mathrm{X}$ obtained a score of $71.25 \%$, this score is still in the sufficient category, for the needs of learning media students get $93.75 \%$ who are in very high qualifications, while for the subject matter, there are two sub-materials that are most difficult for students to understand, namely Concept Visualization which gets a score of $50 \%$ and Digital Books with a score of $43.75 \%$. It became the basis for developers in designing e-book digital simulation-based multimedia.

\section{Design}

The developer begins the design by analyzing the learning that will be carried out in the learning process using a multimedia-based ebook. Based on the results of identifying the needs of students and unstructured interviews with the teacher of Digital Simulation Subject, the developer then compiles a learning implementation plan that is in accordance with the core competencies and basic competencies of the national curriculum implemented in schools.

The development of learning objectives is carried out by the developer by referring to the core competencies, basic competencies, and indicators on each subject matter. Learning objectives are arranged using the ABCD principle, namely audience, behavior, condition, and degree. By setting goals using the $\mathrm{ABCD}$ principle will make teachers and learners implement the learning process more focused and clear to the learning objectives to be achieved by learners.

The preparation of a storyboard is a series of sketch images arranged as a sequence (flow) of elements to be included in the product being developed, namely a multimedia-based digital simulation e-book. The storyboard shows images in the form of multimedia-based e-book sketches that will be developed, such as e-book arrangement, text position, images, videos, and menus. The product being developed is a multimedia-based e-book in which there is a video developed by the developer himself.

The video that will be inserted in the multimedia-based e-book in the form of a video tutorial is an important element that distinguishes this e-book from other e-books besides design, of course. The first step in making a video is compiling a script. The manuscript that is compiled is not only a guide in making the video visuals but also becomes the narrative in the video. Video tutorials show the steps systematically supported by narration that will make it easier for students.

\section{Development}

The development of learning products in the form of multimedia-based digital simulation e-book for class X SMK Negeri 4 Gowa used the Professional Flip PDF program. The e-book is developed based on the objectives, learning strategies, and storyboards that have been made previously. Meanwhile, the video in the multimedia-based e-book formed as a video tutorial. Video is obtained by doing a video screen on the desktop and audio in the form of a narrative based on a script that has been compiled and then recorded and then put together into a complete video by inserting the instrument music in it.

The e-book which still contains text and images then inserted with a video that has been produced but is still a prototype. Previously, when creating an e-book, the developer had determined the position of the video so that it provided space for the placement of the video. In the prototype multimedia-based e-book, a menu is provided that makes it easier for users to use it. The table of contents has been arranged so that it can function as a hyperlink with the pages according to the contents of the digital simulation multimedia-based e-book. Also, 
users can use the word search menu to get to certain pages more quickly.

Furthermore, the prototypes multimedia-based e-book are validated by media and material experts presentation of validation test data for digital simulation multimedia-based e-book material on concept visualization materials and digital books for class X SMK at SMK Negeri 4 Gowa that have been developed given to material experts to assess which are described as follows:

Table 3. Validation Results by Material Experts

\begin{tabular}{|c|c|c|c|}
\hline No & Aspects & Indicators & Scores \\
\hline \multirow{4}{*}{1} & \multirow{4}{*}{ Content } & The clarity of the presented material & 4 \\
\hline & & Learning materials according to the national curriculum & 5 \\
\hline & & The suitability of the RPP with the presented material & 5 \\
\hline & & $\begin{array}{l}\text { The suitability of the content in multimedia-based e-book with } \\
\text { learning objectives }\end{array}$ & 5 \\
\hline \multirow{3}{*}{2} & \multirow{3}{*}{ Language } & The language used is in accordance with the enhanced spelling & 4 \\
\hline & & Use simple and easy to understand the language & 5 \\
\hline & & Completeness of sentences/ information needed by students & 5 \\
\hline \multirow{3}{*}{3} & \multirow{3}{*}{ Quality } & Provide new knowledge & 5 \\
\hline & & Easy for students to understand & 5 \\
\hline & & Attracts interest and motivates students & 5 \\
\hline 4 & Waktu & $\begin{array}{l}\text { The material in the e-book can be studied according to the } \\
\text { learning time }\end{array}$ & 4 \\
\hline \multicolumn{2}{|c|}{ Average } & & 4.73 \\
\hline
\end{tabular}

The presentation of each aspect of the assessment by the material expert is shown in the following graph

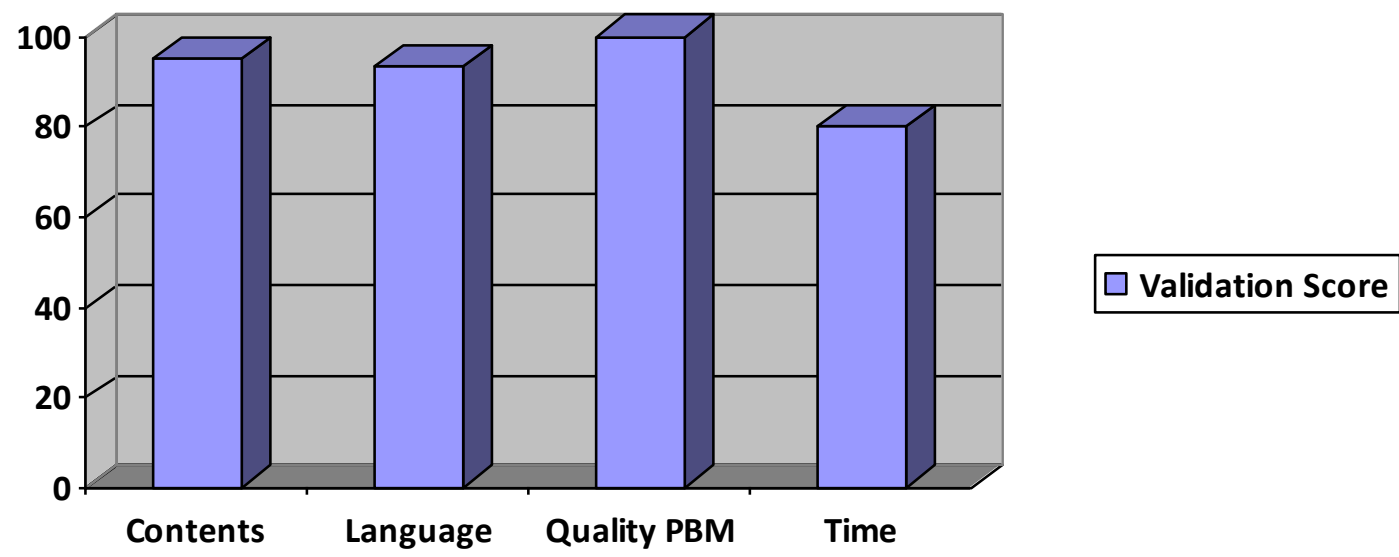

Figure 2. Percentage (\%) Aspects of Material Assessment

The results of the validation of the material/ content based on table 4.5 and figure 2 show that the learning materials included in the multimedia-based e-book obtained a score of 
4.73 with an average percentage of $94.55 \%$ being in the very valid category. These results indicate that the material in the digital simulation of the multimedia-based e-book has met all the material indicators in Digital Simulation learning and can be used without revision.
The next stage of the media validation test/ design of digital simulation multimediabased e-book for grade X Vocational High Schools that has been developed is given to media experts to respond/ assessments which are described as follows.

Table 4. Validation Results by Media Experts

\begin{tabular}{llll}
\hline No & Aspects & Scores & \% \\
\hline 1 & Matching colors, writing, and images & 5 & 100 \\
2 & Image clarity & 5 & 100 \\
3 & The accuracy of selecting the font type and size & 5 & 100 \\
4 & Image and video clarity & 5 & 100 \\
5 & Navigation / buttons regularity & 5 & 100 \\
6 & The accuracy of the color selection on the background & 5 & 100 \\
7 & Synchronize the writing color with the background color & 5 & 100 \\
8 & The learning flow in the media seems clear & 4 & 80 \\
9 & Conformity with learning materials & 4 & 80 \\
10 & The suitability of the media with the learning objectives is conveyed & 5 & 100 \\
11 & Concrete understanding of students & 4 & 80 \\
12 & The color combination is contextual and interesting & 4 & 80 \\
13 & The layout of each page is balanced & 5 & 100 \\
14 & Clarity of sentences (does not lead to multiple interpretations) & 4 & 80 \\
15 & Clarity of the concept of material written in the media & 4 & 80 \\
\hline Average & 4.6 & 92
\end{tabular}

The results of media/ design validation are based on table 4.6, the learning material included in the multimedia-based digital simulation e-book obtained a score of 4.6 with a percentage of $92 \%$ being in the very valid category. The validator provides suggestions that the use of this multimedia-based digital simulation e-book can be accessed offline in the form of an application and pay attention to writing foreign languages. These results indicate that the media/ design of a multimedia-based digital simulation e-book has met the requirements to go to the next stage by making a few revisions.
A multimedia-based digital simulation e-book for grade X Vocational High School, concept visualization material, and digital books was then tested in the learning process at SMK Negeri 4 Gowa. Teachers and students use this e-book in the learning process then provide response assessments individually and in small groups.

The results of responses/ assessments by teachers to multimedia-based digital simulation e-book for class X SMK are described in the following table. 
91 | Vol 7 No 1, April 2021

Table 5. Teacher's Response / Assessment of a multimedia-based digital simulation e-book

\begin{tabular}{llll}
\hline No. & Aspects & Scores & $\mathbf{\%}$ \\
\hline 1 & Facilitate teachers to convey learning objectives easily & 5 & 100 \\
2 & Enabling students in the learning process & 4 & 80 \\
3 & In accordance with the characteristics of various learners & 4 & 80 \\
4 & Easy to use and very helpful in the learning process & 5 & 100 \\
5 & In accordance with the subject matter presented & 5 & 100 \\
6 & The presentation of the material is clear and easy to understand & 5 & 100 \\
7 & The display quality is very good and attractive & 5 & 100 \\
\hline Average & 4.71 & 94,29 \\
\hline
\end{tabular}

The results of the responses/ assessments by the teacher to the multimedia-based digital simulation e-book for class X Vocational High Schools obtained a score of 4.71 with a percentage of $94.29 \%$ being in the very good category. Teachers commented that e-book multimedia-based digital simulation was very helpful and allows teachers to explain the learning material and directing students to understand the subject matter.

Individual trials were conducted on 7 students on a multimedia-based digital simulation e-book which is shown in the following figure.

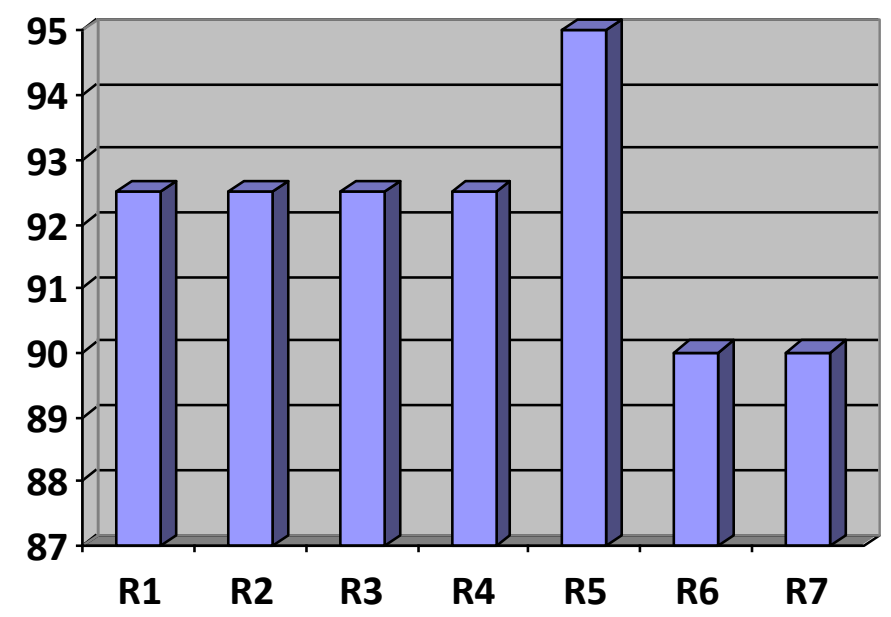

$\square$ Individual Trial

Figure 3. Percentage (\%) Individual Trial

Individual trials conducted on 7 students who got a score of 32.25 with a percentage of $92.14 \%$ were in the very good category.
Student's trial in small groups was carried out by 16 students in 4 groups with the following results. 


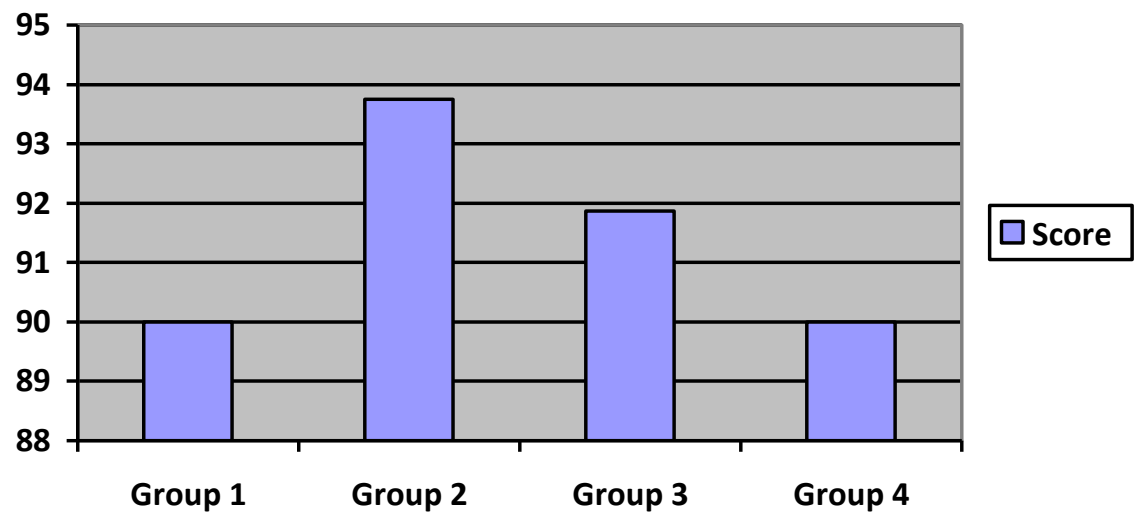

Figure 4. Percentage (\%)Small Group Trial

The small group trials of multimedia-based digital simulation e-book for class X Vocational Schools on concept visualization materials and digital books obtained a percentage score of $90 \%$ in the very good category.

\section{Utilization}

Multimedia-based e-book for digital simulation subjects that have been developed and have met the eligibility and practicality criteria are then used in direct learning. This is intended to see the extent to which the e-book is effective on students' understanding of digital simulation subject matter. At this stage, a pre-test and posttest were carried out on 20 students of class X Computer Engineering and Networks for Digital Simulation Subjects. The pre-test is given before using the e-book, after that the teacher and students carry out the learning process using a multimedia-based e-book by utilizing all the features in it. After using the e-book, then a posttest is given to students. The results of the students' pre-test and post-test are described in the following table.

Table 6. The results of pre-test and post-test

\begin{tabular}{cccc}
\hline Students & Pre-Test & Post-Test & N Gain \\
\hline 1 & 73 & 86 & 0,5 \\
2 & 70 & 86 & 0,5 \\
3 & 78 & 92 & 0,6 \\
4 & 71 & 90 & 0,7 \\
5 & 71 & 92 & 0,7 \\
6 & 76 & 90 & 0,6 \\
7 & 73 & 80 & 0,3 \\
8 & 77 & 86 & 0,4 \\
9 & 77 & 80 & 0,1 \\
10 & 77 & 92 & 0,7 \\
11 & 75 & 90 & 0,6 \\
12 & 78 & 86 & 0,4 \\
13 & 78 & 92 & 0,6 \\
14 & 70 & 80 & 0,3 \\
15 & 73 & 95 & 0,8 \\
16 & 71 & 80 & 0,3 \\
17 & 71 & 93 & 0,8 \\
18 & 76 & 93 & 0,7 \\
19 & 73 & 86 & 0,5 \\
20 & 75 & 80 & 0,2 \\
\hline
\end{tabular}


An Increase in Learning Outcome Students outcomes described in the following chart

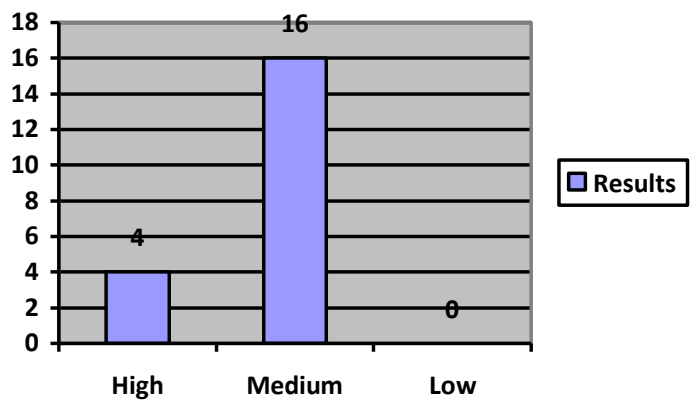

Figure 5. An Increase in student Pre-Test and Post Test Score

The results of data analysis on the pre-test and post-test scores of students showed an increase in the high category of 4 people, being 16 people, and no one in the low category in using multimedia-based e-book in digital simulation subjects. Thus, digital simulation learning using a multimedia-based e-book can improve the learning outcomes of students effectively.

\section{Evaluation/ Assesment}

Multimedia-based e-book utilized and developed through validation, trials have met the criteria for feasibility and practicality as well as effectiveness. From each of these stages, an evaluation is carried out to see the deficiencies contained in this multimedia-based e-book. These deficiencies are then corrected and developed so that they can be maximally used in learning. The following displays a multimediabased e-book on digital simulation subjects for class X Vocational High Schools.

Table 7. The Display of digital simulation of Multimedia-Based E-book

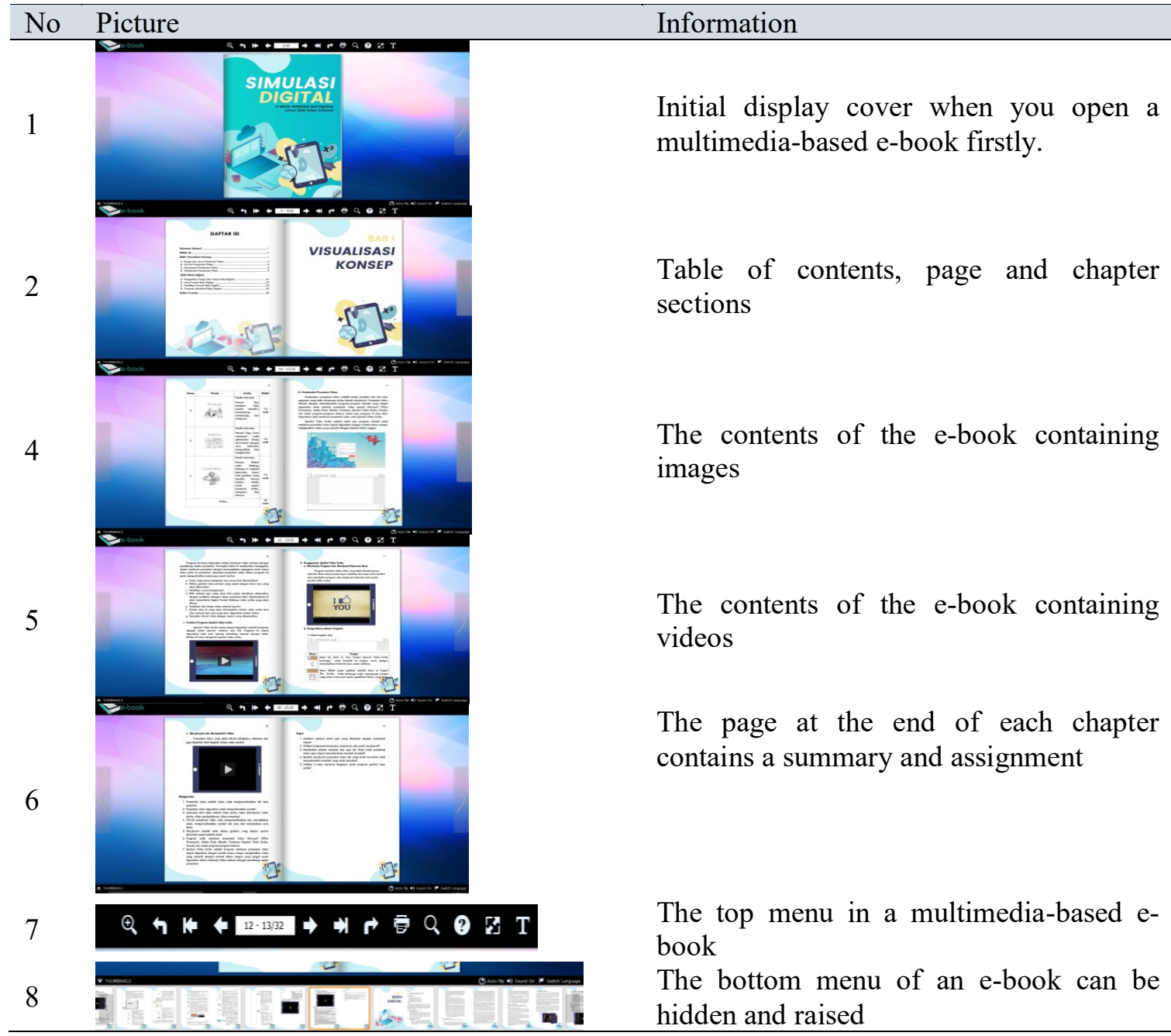




\section{Discussion}

The need for learning product development in this study was obtained from curriculum analysis and student characteristics analysis. The developer then analyzed material and media needs which showed students had difficulty understanding the conceptualization and digital book visualization subject matter, while the students' media needs were learning resources such as books that did not only contain text and images but also videos that could provide a clearer explanation of the material and can also be played back. Firdaus \& Untari (2020) stated that in line with the statement, based on research conducted on the development of digital books that states that digital books are developed based on the needs of teachers and students in schools that can help implement the learning process more effectively and interactively. The development of a multimedia-based digital simulation e-book was developed by using the ADDIE (Analysis, Design, Development, Implementation, and Evaluation) model. This multimedia-based ebook development stage only reaches the development stage. Step by step has been implemented based on development needs. This multimedia-based digital simulation e-book is in the form of a file so it is very practical to be used via computers, tablets, and smartphones with simple menus so that it is easy to be used by the teachers and the students. According to Subiyantoro (2014) the benefits of the e-book are more practical and easy to be carryied, moreover it is environmentally friendly, durable, more simple, cheaper, and much more portable.

The presentation of multimedia-based digital simulation e-book material is not only in the form of text and images but also video but also the combination design of the color display, background, hyperlinks, and page-moving animation in the e-book attracts the attention of students. According to Plangsorn \& Poopan (2017), E-book does not only contain text and images but insert multimedia elements such as video, audio, animation, and hyperlinks. Meanwhile, according to Arsyad (2014) multimedia is something that aims to convey information that is fun, interesting, easy to understand, and clear. Based on this, the use of text, images, videos, and animations in this multimedia-based digital simulation e-book is adjusted to the needs of students so that it can help teachers explain the subject matter and students easily understand the subject matter.

The findings obtained in this study are the production of a digital simulation e-book multimedia-based concept visualization materials and digital books that are valid and suitable for use with very good criteria. Multimedia-based digital simulation e-book has been said to be valid and feasible because it has gone through the development process starting from the results of the needs analysis to the production stage which is then validated by material/content experts and media/design experts. The results of material/content validation obtained a score that was in the very valid category, which means that the material in the e-book developed was in accordance with the goals and needs of students. Furthermore, the results of the media/design expert validation obtained a score that was in the very valid category, which means that the e-book design developed was in accordance with the material and needs of students even though there was still a slight revision based on notes provided by the validator regarding foreign language writing.

The developer reviewed the multimediabased digital simulation e-book for revision, especially for foreign language writing, then a trial was conducted to obtain responses/ assessments from teachers and students. The results of the analysis of teacher responses to the multimedia-based digital simulation e-book obtained a score that was in the very good category. Furthermore, through individual trials to 7 students obtained scores that were in the very good category. While the small group trial of 16 students who were divided into 4 groups obtained a score that was in the very good category. From the results of the responses/ assessments by teachers and students, it shows that they have no difficulty using the multimedia-based digital simulation e-book that has been developed.

The results of this development indicates that this multimedia-based digital simulation e-book is very easy to use by the teachers and the students, besides it can help teachers and students in explaining and understanding learning material. Yachina (2016) argued that the use of ebooks can provide information not only in the form of text, but also through audio visuals so that it allows students to focus on learning and contribute to better understanding and storage of information. Meanwhile, according to Ahmad (2014)learning 
media that contain multimedia consisting of images, video, animation, text, and audio are very useful for students as they make it very easy and help in the learning process.

Multimedia-based digital simulation ebook make teachers easy to explain the subject matter to students so that a learning process is created that is not on teacher-centered but on the students who are active in learning. According to Wardani (2016), multimedia-based e-book allow learner-centered learning activities and provide interaction between students and ebook. Koh \& Herring (2016) also believed that e-books are easy to access or use, easy topic search, which can be accessed anywhere and anytime, display more attractive, cheaper and practical in small file storage.

The use of a multimedia-based digital simulation e-book in a computer laboratory through the teacher displaying the e-book through a projector then students open the ebook through the computer in front of them. The use of digital simulation e-book with computers/ laptops during learning because project tasks that must be done by students can only be done through a computer/laptop. This multimediabased digital simulation e-book allows students to interact directly with the e-book to learn and follow step by step in working on project assignments, making video presentations, and digital books. This is in accordance with the findings of Glackin (2014) which stated that the use of e-books that contain a combination of media elements can have a positive impact on student learning experiences. Purwaningtias \& Solikin (2017) in their research article on the application of e-book school application at SMK Emhata OKI stated that teachers as one of the new learning media, which can make it easier for teachers to provide subject teaching materials and also assignments to students even though the teacher is not present in the school so that students do not experience the importance of teaching materials. And with this e-book school application makes it easier for students to get teaching materials from teachers and the ebook can be brought and opened by students or teachers through the use of mobile phones that support be able to open this e-book.

Multimedia-based digital simulation ebook, concept visualization materials, and digital books are very suitable for use in learning because the subject matter is in accordance with the needs and characteristics of students, learning objectives, and makes teachers and students easier in the learning process. The use of multimedia-based digital simulation e-book is also very easy for teachers and students with simple buttons and menus in them. The design and animation e-book is very interesting, very fun to use for learners because in addition to interact directly with the e-book, it is also quick to understand the subject matter.

\section{CONCLUSIONS AND SUGGESTIONS}

Based on the results of the curriculum study, the characteristics and the needs of the students' material and media in the multimediabased digital simulation e-book was successfully tested. Students need books not only in the form of files which is containing text and images but also the book that can provide direct experience in the form of videos containing simulations of events that are in accordance with the material being taught. Digital simulation e-book is specially designed with the selection of images, colors, videos, and other elements so that they are easy to be used by teachers and students. The development of a multimedia-based digital simulation e-book was declared valid and practical (easy to use) in learning. The results of expert validation, teacher responses, individual trials, and group trials are in the very good category and the use of multimedia-based ebook can also improve students' learning outcomes effectively.

\section{ACKNOWLEDGMENTS}

Thanks to the Rector of the State University of Makassar for his funding so that this research can run smoothly.

\section{REFERENCES}

Acharya, A. S., Prakash, A., Saxena, P., \& Nigam, A. (2013). Sampling: Why and how of it. Indian Journal of Medical Specialties, 4(2), 330-333.

Ahmad, M. (2014). Cara aktif membuat CD interaktif. Jakarta: Elex Media Komputindo.

Akdon, R. (2013). Rumus dan Data Analisis Statistika. Bandung: Alfabeta.

$\begin{array}{cc}\text { Anggraini, L. } & \text { (2014). Analisis Persepsi } \\ \text { Konsumen } & \text { Menggunakan Metode } \\ \text { Importance Performance Analysis dan }\end{array}$


Customer Satisfaction Index (Studi Kasus Di Ria Djenaka Coffee \& Resto, Malang. Universitas Brawijaya.

Arsyad, A. (2014). Media Pembelajaran. jakarta: Rajawali Pers.

Cahyadi, R. A. H. (2019). Pengembangan Bahan Ajar Berbasis ADDIE Model. Halaqa: Islamic Education Journal, 3(1), 35-42.

Devi, P. C., Hudiyono, Y., \& Mulawarman, W. G. (2018). Pengembangan Bahan Ajar Menulis Teks Prosedur Kompleks dengan Model Pembelajaran Discovery Learning Menggunakan Media Audio Visual (Video) di Kelas XI SMA Negeri 1 Samarinda. Diglosia: Jurnal Kajian Bahasa, Sastra, Dan Pengajarannya, 1(2), 101-114.

Firdaus, A. F., \& Untari, R. S. (2020). Pengembangan Buku Digital Berbasis Android Mata Pelajaran Jaringan Dasar Di SMK DIAN Indonesia. JICTE (Journal of Information and Computer Technology Education), 4(2), 7-14.

Fojtik, R. (2015). Ebooks and mobile devices in education. Procedia-Social and Behavioral Sciences, 182, 742-745.

Glackin, B. C., Rodenhiser, R. W., \& Herzog, B. (2014). A library and the disciplines: A collaborative project assessing the impact of eBooks and mobile devices on student learning. The Journal of Academic Librarianship, 40(3-4), 299-306.

Koh, H., \& Herring, S. C. (2016). Historical insights for ebook design. Library Hi Tech.

Maribe, R. (2009). Instructional Designe: The ADDIE Aproach. doi: 10.1007.

Miftah, M. (2013). Fungsi, dan peran media pembelajaran sebagai upaya peningkatan kemampuan belajar siswa. Jurnal Kwangsan, 1(2), 95.

Moller, J. (2014). Comparing electronic short books from the USA and the UK to South Africa: Can they be successful in the South African trade book sector? The Electronic Library.

Plangsorn, B., \& Poopan, S. (2017). Development of Producing and Using EBooks Competencies of Teachers in Chachengsao, Thailand. World Journal on Educational Technology: Current Issues,
$9(2), 112-117$.

Pratama, L. D., Lestari, W., \& Bahauddin, A. (2019). Game Edukasi: Apakah membuat belajar lebih menarik? At-Ta'lim: Jurnal Pendidikan, 5(1), 39-50.

Purwaningtias, F., \& Solikin, I. (2017). Penerapan Aplikasi e-book school pada SMK Emhata OKI Sumsel berbasis Web. JUST IT: Jurnal Sistem Informasi, Teknologi Informasi Dan Komputer, 8(1), 21-30.

Putra, N. (2012). Research \& Development penelitian dan pengembangan. Jakarta: Raja Gravindo Persada.

Rockinson-Szapkiw, A. J., Courduff, J., Carter, K., \& Bennett, D. (2013). Electronic versus traditional print textbooks: A comparison study on the influence of university students' learning. Computers \& Education, 63, 259-266.

Rvachew, S., Rees, K., Carolan, E., \& Nadig, A. (2017). Improving emergent literacy with school-based shared reading: Paper versus ebooks. International Journal of ChildComputer Interaction, 12, 24-29.

Sanjaya, W. (2019). Strategi pembelajaran berorientasi standar proses pendidikan.

Santoso, T. N. B., Siswandari, S., \& Sawiji, H. (2018). The effectiveness of eBook versus printed books in the rural schools in Indonesia at the modern learning era. International Journal of Educational Research Review, 3(4), 77-84.

Subiyantoro, E. (2014). Menapak di Era Digital dengan Memasyarakatkan Buku Digital.

Wardani, R., Nugroho, L. E., \& Rochayati, U. (2016). Design of Interaction Model for interactive E-Book. International Conference on Engineering and Science for Reasearch and Development, 1-7.

Yachina, N. P., Valeeva, L. A., \& Sirazeeva, A. F. (2016). E-Teaching Materials as the Means to Improve Humanities Teaching Proficiency in the Context of Education Informatization. International Journal of Environmental and Science Education, 11(4), 433-442. 